\title{
Bidirectional spillover effect between Russian stock index and the selected commodities*
}

\author{
Dejan Živkov ${ }^{1}$, Jovan Njegić2 ${ }^{2}$ Mirela Momčilović3
}

\begin{abstract}
This paper investigates shock and volatility spillover effect between Russian index RTS and six futures commodities (Brent oil, natural gas, gasoline, gold, platinum and palladium), observing joint time-frequency domain via wavelet decomposed series. Due to the fact that our time-span of almost 16 years is permeated with tranquil and crisis periods, we divided full-sample into three subsamples - before, during and after World financial crisis (WFC) via modified ICSS algorithm. We find that spillover effects happen mostly from the commodity markets toward RTS index in all three subsamples. However, during relatively calm periods (first and third sub-periods), spillover effects are very moderate and they occur in relatively few wavelet scales, which points that duration of these effects is limited in peaceful times. On the other hand, duration of spillover effects and its intensity increased during WFC. Also, wavelet coherence indicates that there are areas of stronger co-movements in period of WFC at higher wavelet scales for pairs such as RTS-Brent, -gasoline and-platinum. Commodities that have the strongest transmission effect on RTS index are Brent oil, gasoline and palladium, while gold has strong volatility transmission only during WFC.
\end{abstract}

Key words: commodities, spillover effect, MODWT, BEKK-GARCH, wavelet coherence

JEL classification: C51, C63, G15

\footnotetext{
* Received: 22-11-2017; accepted: 07-06-2018

1 Lecturer, Novi Sad school of business, Vladimira Perića Valtera 4 University of Novi Sad, 21000 Novi Sad, Serbia. Scientific affiliation: Econometrics, international finance, macroeconomics. Phone: +38160144 5598. Fax: +381 21635 0367. E-mail: dejanzivkov@gmail.com. Personal website: https://www.vps.ns.ac.rs/(corresponding author).

2 Professor, Novi Sad school of business, Vladimira Perića Valtera 4, University of Novi Sad, 21000 Novi Sad, Serbia. Scientific affiliation: Econometrics, portfolio finance, macroeconomics. Phone: +3816250 2345. Fax: +38121635 0367.E-mail: jovan.nj@gmail.com.Personal website: https://www.vps.ns.ac.rs/.

3 Teaching assistant, Novi Sad school of business, Vladimira Perića Valtera 4, University Novi Sad, 21000 Novi Sad, Serbia. Scientific affiliation: Portfolio finance, business finance, financial markets.Phone: +38163280 130.Fax:+38121635 0367.E-mail: bizniscentar@gmail.com. Personal website: https://www.vps.ns.ac.rs/.
} 


\section{Introduction}

A well-known fact in the international financial community is that commodity prices experienced an exceptional volatility throughout the last two decades, which was fueled by the various global events and crisis. These volatilities in commodity prices can have impact on the various segments of national macroeconomy. As asserted by Van der Ploeg and Poelhekke (2009), it is particularly true for rawmaterial exporting emerging markets that are less resistant to the commodity markets shocks due to the lack of the efficient financial-market tools required to mitigate such shocks. In the paper of Hegerty (2016), the author contended that commodity-price volatility not only can affect country's output and exchange rate with the potential to feed inflation pressures, but it can also force policymakers to implement countercyclical measures, with the subsequent impacts on interest rates. In order to demonstrate the importance of this issue and to discuss it, the G20 countries gathered at Pittsburgh summit in September 2009. Besides, portfolio and risk managers are particularly keen to grasp the level of spillover effect that comes from the commodity markets since raw materials frequently serve as an auxiliary asset in investment portfolios, together with stock classes (see e.g. Kirkulak-Uludag and Lkhamazhaoov, 2017). Therefore, an increasing interest exists in last two decades among policy makers, portfolio investors and risk hedgers to model and gauge the mean and volatility spillovers between various commodities and stocks (see e.g. Nazlioglu et al., 2013).

However, most researchers that have been studying the cross-market volatility spillover effects, observed this phenomenon via only time dimension, neglecting the frequency dimension characteristics that exist in financial time series. Conlon and Cotter (2012) explained that due to the sample reduction problem associated with matching the frequency of data with the different time horizons, the analysis of multiscale spillover effect has been little studied. This issue could be very important as Živkov et al. (in press) contended, because the market nexus could differ across time scales and the features in frequency dimension can help in better apprehension of complex pattern of the cross-market shock spillover effects.

Common knowledge is that Russia is one of the biggest energy and precious metals producers in the world. Thus, this paper strives to explore bidirectional shock and volatility transmission effect between Russian RTS index and the six futures commodities (Brent oil, natural gas, gasoline, gold, platinum and palladium), covering 16 years of time-span. The spillover effect is studied via five different frequency dimensions (time-horizons), which extend volatility spillovers between time series into joint time-frequency domain. For that purpose, we use a relatively novel approach - Maximum Overlap Discrete Wavelet Transformation (MODWT), which is a powerful mathematical tool for a time-frequency representation of a time-series. Unlike traditional methodologies, MODWT is able to observe different 
time-horizons without shrinking the sample size and without the wastage of the valuable information. The idea to adopt wavelet analysis in spillover framework came from very few recent papers - Dajčman (2013), Barunik and Vacha, (2013) and Liu et al. (2017), who considered the idea to observe the cross-market spillover effect via different wavelet scales. As complementary analysis, we try to assess in which time period and over the wavelet scales high correlation between RTS index and selected commodities exists, which might help portfolio analysts, risk hedgers and global investors who combine these two assets. These calculations are conducted via wavelet squared coherence.

Bidirectional spillover effect measurement between Russian index and six commodities is conducted via multivariate $\operatorname{GARCH}(1,1)$ model with full BEKK parameterizations for the variance equation. Additionally, in order to consider the evolution of spillover effects at different time-periods, which were characterized by different market conditions, we split the full sample period into three sub-periods, pre-, during-, and post- world financial crisis (WFC) by utilizing non-arbitrary method of detecting structural breaks between sub-periods. For that purpose, we employ modified Iterative Cumulative Sum of Squares (ICSS) algorithm of Sansó et al. (2004). To the best of our knowledge, this is the first paper among extant literature that investigates comprehensively and thoroughly the issue of bidirectional shock and volatility spillover effect between Russian RTS index and various commodity markets, also observing several different time horizons via wavelet approach and three distinctive time periods.

Beside introduction, this paper is structured as follows. Second section gives a survey of the literature that considers underlying topic. Third section presents the utilized methodologies - MODWT approach, wavelet coherence, full BEKKGARCH model and modified ICSS algorithm. Fourth section is reserved for dataset and descriptive statistics. Fifth section discloses the results of bidirectional spillover effect. The results of wavelet coherence are explained in sixth section and last section concludes.

\section{Brief literature review}

Some papers such as Bein and Aga (2016), Yildirim et al. (2015), Ho and Huang (2016), Cunado and de Gracia (2014), Filis and Chatziantoniou (2014), Kurshid and Uludag (2017) found negative transmission effect between oil prices and stock market returns. Other research papers stipulated positive nexus between oil prices and stock return movements (see inter alia Bjornland, 2009; Narayan and Narayan, 2010; Arouri and Rault, 2012; Shamsollah and Maryam, 2011; Mahmoodi, 2017). Hayo and Kutan (2005) investigated Russian case and they disclosed that Russian stock market is sensitive to oil price in a sense that oil 
price movements may significantly destabilize Russian markets. As for spillover nexus between stocks and non-oil commodities, very few papers deal with this issue. For instance, the manuscript of Mensi et al. (2013) used VAR-GARCH model to investigate the return links and volatility transmission between the S\&P500 and commodity price indices for energy, food, gold and beverages over the period from 2000 to 2011 .

For return and volatility spillover, they found significant transmission among the S\&P500 and commodity markets, particularly oil, while the analysis revealed that these spillovers have substantially increased during the crisis period. The research paper of Raza et al. (2016) examined the asymmetric impact of gold prices, oil prices and their associated volatilities on stock markets of emerging economies. They concluded that gold prices have a positive impact on stock market prices of large emerging BRICS economies and a negative impact on the stock markets of Mexico, Malaysia, Thailand, Chile and Indonesia. On the other hand, oil prices have a negative impact on stock markets of all emerging economies. Also, they found that gold and oil volatilities have a negative impact on stock markets of all emerging economies in both the short-and the long-run.

\section{Methodology}

\subsection{Wavelet multi-resolution approach}

Wavelet methodology has capability to decompose a time series into its highand low-frequency components associated with different scales of resolution, that is, it projects the original series onto a sequence of basic functions that are called wavelets. Referring to Gencay et al. (2002), wavelets permit an appropriate trade-off between resolution in the time and frequency domains, and overcomes shortcomings of traditional Fourier analysis, in terms that it only stresses the frequency domain at the expense of the time domain. Wavelet theory provides an efficient and convenient method to analyse complex signals. There are two basic wavelet functions: the father wavelet $(\varphi)$ and the mother wavelet $(\psi)$. Wavelets are nonlinear functions that can be rescaled and moved to form a basis in a Hilbert space of square integrable functions $\left(f \in L^{2}\right)$. The father wavelets augment the representation of the smooth or low frequency parts of a signal with an integral equal to 1 , and the mother wavelets are helpful in describing the details of high frequency components with an integral equal to 0 . The father wavelet pictures the long-term trend over the scale of the time series, whilst the mother wavelet delineates fluctuations in the trend. The most commonly used wavelets are the orthogonal ones and the approximation to a continuous signal series $y(t)$ in $L^{2}(R)$ is as following: 


$$
y(t) \approx \sum_{k} s_{J, k} \phi_{J, k}(t)+\sum_{k} d_{J, k} \psi_{J, k}(t)+\sum_{k} d_{J-1, k} \psi_{J-1, k}(t)+\ldots+\sum_{k} d_{1, k} \psi_{1, k}(t),
$$

where symbol $\mathrm{J}$ denotes the number of multi-resolution components or scales, and $\mathrm{k}$ ranges from 1 to the number of coefficients in the corresponding component. The coefficients $s_{\mathrm{J}, \mathrm{k}}, \mathrm{d}_{\mathrm{J}, \mathrm{k}}, \ldots, \mathrm{d}_{1, \mathrm{k}}$ stand for the wavelet-transform coefficients that can be approximated by the following integrals:

$$
\begin{aligned}
& s_{J, k} \approx \int y(t) \varphi_{J, k}(t) d t, \\
& d_{J, k} \approx \int y(t) \psi_{J, k}(t) d t, \quad j=1,2, \ldots, J .
\end{aligned}
$$

These coefficients portray a measure of the contribution of the corresponding wavelet function to the total signal. Whereas the functions $\varphi_{J, k}$ and $\psi_{J, k}$ are the approximating wavelet functions, in other words the scaled and translated versions of $\varphi$ and $\psi$. These functions are generated from $\varphi$ and $\psi$ in the following way:

$$
\phi_{J, k}(t)=2^{-J / 2} \phi\left(\frac{t-2^{J} k}{2^{J}}\right), \quad \psi_{J, k}(t)=2^{-J / 2} \psi\left(\frac{t-2^{J} k}{2^{J}}\right) .
$$

According to the expression (4), the scale or dilation factor is $2^{\mathrm{J}}$, whereas the translation or location parameter is $2^{\mathrm{J}} \mathrm{k}$. As much as $\mathrm{J}$ grows, so does the scale factor $2^{J}$, which is a measure of the width of the functions $\varphi_{J, k}(t)$ and $\psi_{J, k}(t)$, and it affects the underlying functions to get shorter and more dilated. When $\mathrm{J}$ gets larger, the translation steps automatically increases in order to accommodate the level of scale parameter $2^{\mathrm{J}}$.

For our empirical research we utilize the maximum overlap discrete wavelet transformation (MODWT), which is linear filtering operation that transforms a series into coefficients related to variations over a set of scales. For multi-resolution analysis in MODWT, the decomposed signals are given in the following way:

$$
\begin{aligned}
& S_{j}(t)=\sum_{k} s_{J, k} \phi_{J k}(t), \\
& D_{j}(t)=\sum_{k} d_{J, k} \psi_{J, k}(t) \quad j=1,2, \ldots, J,
\end{aligned}
$$

where symbols $\operatorname{Sj}(\mathrm{t})$ and $\mathrm{Dj}(\mathrm{t})$ represent the fluctuation and scaling coefficients, respectively, at the $\mathrm{j}$-th level wavelet that reconstructs the signal in terms of a specific frequency (trending and fluctuation components). An empirical time series $y(t)$ can be expressed in terms of those signals as:

$$
y(t)=S_{j}(t)+D_{j}(t)+D_{j-1}(t)+\ldots+D_{1}(t) .
$$


We perform multiresolution analysis with five levels of time scales using MODWT with Daubechies least asymmetric (LA) wavelet filter of length $\mathrm{L}=8$, which is also known as LA(8) wavelet filter.

\section{Wavelet coherence and phase difference}

The wavelet coherence technique is a suitable tool that can detect regions in the time-frequency space where the inspected time series co-move and can be defined as the ratio of the cross-wavelet spectrum, which is the product of the spectrum of each examined series and is treated as the local correlation, both in time and frequency. Vacha and Barunik (2012) explained that wavelet coherence measures the local linear correlation between two stationary time series at each scale, and it is equivalent to the squared correlation coefficient in linear regression. Referring to Torrence and Webster (1999), we define the squared wavelet coherence coefficient as:

$$
R^{2}(u, s)=\frac{\left|S\left(s^{-1} W_{x y}(u, s)\right)\right|^{2}}{S\left(s^{-1}\left|W_{x}(u, s)\right|^{2}\right) S\left(s^{-1}\left|W_{y}(u, s)\right|^{2}\right)},
$$

where $S($.$) is a smoothing operator and s$ is a wavelet scale. The squared wavelet coherence coefficient is in the range $0 \leq R 2(u, s) \leq 1$, where values near zero point to weak correlation, while values near one indicate strong correlation. The Wavelet Coherence is estimated utilizing Monte Carlo methods.

The wavelet coherence analysis cannot distinguish whether dependence is positive or negative because the wavelet coherence is squared. Thus, we also consider wavelet coherence phase differences, which delineates details about the delays in the oscillation (cycles) between the two time series under study. Following Torrence and Webster, 1999, the wavelet coherence phase difference is defined as follows:

$$
\varphi_{x y}(u, s)=\tan ^{-1}\left(\frac{\mathfrak{I}\left\{S\left(s^{-1} W_{x y}(u, s)\right)\right\}}{\Re\left\{S\left(s^{-1} W_{x y}(u, s)\right)\right\}}\right) .
$$

Phase difference between two series ( $\mathrm{x}, \mathrm{y})$ is indicated by arrows on the wavelet coherence plots. When arrows point to the right (left) it means that the time series are in-phase (anti-phase) or are positively (negatively) correlated. If arrows point to the right and up, the second variable is lagging and if they point to the right and down, the second variable is leading. Reversely, if arrows point to the left and up, the second variable is leading and if arrows point to the left and down, the second variable is lagging. 


\subsection{BEKK-GARCH model}

This subsection concisely explains full BEKK-GARCH model of Engle and Kroner (1995) that is used for the calculation of spillover effect between selected commodities and Russian RTS index, whereby it is observed via five wavelet scales. For every RTS-commodity pair we assume only constant in the mean equation specification and it has the following expression at the wavelet scale $j$ :

$$
y_{i, t}(j)=C_{i}+\varepsilon_{i, t}(j) ; \quad \varepsilon_{i, t}(j) \sim i i d
$$

Before wavelet transformation, all empirical asset returns $(i)$ are calculated as $r_{i, t}=\ln \left(P_{i, t} / P_{i, t-1}\right) \times 100$, where $P_{i, t}$ is the closing price at time $(t) \cdot y_{i, t}(j)$ is $2 \times 1$ vector of wavelets, $y_{i, t}(j)=\left[r_{R T S, t}(j), r_{\text {commodity, }}(j)\right]^{\prime}$, containing RTS index wavelet returns and the wavelet returns of the selected commodities at time $t$. Symbol $\varepsilon_{t}(j)$ stands for $2 \times 1$ vector of for independently and identically distributed error terms of selected time-series at scale $j, \varepsilon_{i, t}(j)=\left[\varepsilon_{R T S, t}(j), \varepsilon_{\text {commodity,t }}(j)\right]^{\prime}$. Our conjecture is that wavelet residual distributions at all scales most likely tend to report non-normality features such as asymmetry and leptokurtosis, so we opt for standard Student t distribution in every full BEKK-GARCH model. According to Njegić et al. (in press), this model provides a cross-market shock and volatility effects in the conditional variance equation and accordingly, full BEKK-GARCH model with wavelets has the following form of the matrix $\mathrm{H}_{\mathrm{t}}$ :

$$
H_{t}(j)=\bar{\omega}^{\prime} \bar{\omega}+A^{\prime} \varepsilon_{t-1}(j) \varepsilon^{\prime}{ }_{t-1}(j) A+B^{\prime} H_{t-1}(j) B,
$$

where Ht denotes a $2 \times 2$ matrix of conditional variance-covariance at time $t$, and $\bar{\omega}$ is a $2 \times 2$ lower triangular matrix of constants with three parameters. Symbol A represents a $2 \times 2$ square matrix of parameters and measures the extent to which conditional variances are correlated with past squared errors. Statistically significant diagonal elements in matrix B measure their own GARCH effect, implying that current conditional variance is affected by their own past conditional volatility. Engle and Kroner (1995) asserted that the above system can be efficiently and consistently estimated by using full information maximum-likelihood method. We employ the BFGS (Broyden, Fletcher, Goldfarb, Shanno) algorithm to obtain the final estimate of the variance-covariance matrix and the corresponding standard errors.

\subsection{Modified ICSS algorithm}

Beside full sample estimation, we also measure spillover effect observing three distinctive time periods - pre-, during- and post-WFC. In order to do that, we split full sample into three subsamples, and the benchmark is exact break dates around the WFC that is determined by the same non-arbitrary method as in the paper of Mensi et al. (2016). They utilized modified ICSS algorithm of Sans'o et al. (2004) 
to detect exact date of the WFC outbreak and thereafter divided full sample into two subsamples according to these breaks. This particular methodology overcomes the problem of oversized break detection, which is the prime shortcoming of basic ICSS algorithm of Inclan and Tiao (1994). Modified ICSS explicitly takes into account the fourth moment properties of the time series. The Modified Inclan and Tiao (MIT) empirical statistics, using a non-parametric adjustment based on Bartlett and Kernel, is presented by:

$$
M I T=\sup _{k}\left|T^{-0.5} G_{k}\right|,
$$

where

$G_{k}=\hat{\lambda}^{-0.5}\left[C_{k}-(k / T) C_{T}\right] ; \hat{\lambda}=\hat{\gamma}_{0}+2 \sum_{l=1}^{m}\left[1-l(m+1)^{-1}\right] \hat{\gamma}_{l} ; \hat{\gamma}_{l}=T^{-1} \sum_{t=l+1}^{T}\left(\tau_{t}^{2}-\hat{\sigma}^{2}\right)\left(\tau_{t-1}^{2}-\hat{\sigma}^{2}\right) ;$

$\hat{\sigma}^{2}=T C_{T}^{-1}$. Referring to the procedure of Newey and West (1994), we set the lag truncation parameter to be $m=0.75 T^{1 / 3}$. The asymptotic distribution of the MIT statistics under general conditions is given by $\sup _{l}\left|W^{*}(l)\right|$ and the 95th percentile critical value for the asymptotic distribution of MIT statistics is 1.4058 .

\section{Empirical data and results}

For the purpose of bidirectional spillover effect assessment, this paper uses daily data of Russian stock index RTS, and six daily futures commodities - Brent oil, natural gas, gasoline, gold, platinum and palladium. All daily empirical series are transformed in five levels of time scales via MODWT algorithm. In such way, we are able to gauge the complex shock and volatility transmission effects that took place in different time horizons, which correspond to: scale 1 (D1) 2 days, scale 2 (D2) 4 days, scale 3 (D3) 8 days, scale 4 (D4) 16 days and scale 5 (D5) 32 days. By using five wavelet scales, we are able to evaluate spillover effects in short term (scales 1 and 2) and midterm (scales 3, 4 and 5). Full sample covers time-span from January 2001 to December 2016 and all series were obtained from Datastream. Due to unavailability of some data which is caused by the non-working days in various asset markets, all commodities were synchronized with RTS index according to the existing observations. 
Dejan Živkov, Jovan Njegić, Mirela Momčilović • Bidirectional spillover effect between...

Zb. rad. Ekon. fak. Rij. • $2018 \cdot$ vol. $36 \cdot$ no. $1 \cdot 29-53$

Table 1: Summary statistics for selected assets and across wavelets

\begin{tabular}{|c|c|c|c|c|c|}
\hline $\begin{array}{c}\text { Descriptive statistics } \\
\text { of selected assets }\end{array}$ & D1 & D2 & D3 & D4 & D5 \\
\hline \multicolumn{6}{|c|}{ RTS } \\
\hline Mean & 0 & 0 & 0 & 0 & 0 \\
\hline Standard deviation & 1.443 & 1.116 & 0.863 & 0.574 & 0.383 \\
\hline Skewness & 0.202 & 0.153 & 0.367 & 0.111 & -0.382 \\
\hline Kurtosis & 7.208 & 6.197 & 8.579 & 5.515 & 1.119 \\
\hline JB test (p-values) & 0 & 0 & 0 & 0 & 0 \\
\hline \multicolumn{6}{|c|}{ Brent oil } \\
\hline Mean & 0 & 0 & 0 & 0 & 0 \\
\hline Standard deviation & 1.591 & 1.025 & 0.760 & 0.502 & 0.347 \\
\hline Skewness & -0.037 & 0.027 & 0.058 & -0.125 & -0.094 \\
\hline Kurtosis & 2.518 & 1.607 & 2.942 & 1.878 & 0.266 \\
\hline JB test (p-values) & 0 & 0 & 0 & 0 & 0 \\
\hline \multicolumn{6}{|c|}{ Natural gas } \\
\hline Mean & 0 & 0 & 0 & 0 & 0 \\
\hline Standard deviation & 2.669 & 1.726 & 1.194 & 0.782 & 0.550 \\
\hline Skewness & -0.221 & 0.089 & 0.018 & -0.045 & 0.030 \\
\hline Kurtosis & 22.029 & 4.030 & 1.082 & 0.866 & 0.791 \\
\hline JB test (p-values) & 0 & 0 & 0 & 0 & 0 \\
\hline \multicolumn{6}{|c|}{ Gasoline } \\
\hline Mean & 0 & 0 & 0 & 0 & 0 \\
\hline Standard deviation & 1.929 & 1.396 & 1.024 & 0.640 & 0.398 \\
\hline Skewness & -0.141 & 0.122 & 0.027 & -0.155 & -0.005 \\
\hline Kurtosis & 3.938 & 7.934 & 8.027 & 3.695 & 0.112 \\
\hline JB test (p-values) & 0 & 0 & 0 & 0 & 0.357 \\
\hline \multicolumn{6}{|c|}{ Gold } \\
\hline Mean & 0 & 0 & 0 & 0 & 0 \\
\hline Standard deviation & 0.832 & 0.580 & 0.398 & 0.302 & 0.216 \\
\hline Skewness & -0.061 & -0.069 & -0.037 & 0.010 & -0.335 \\
\hline Kurtosis & 3.020 & 2.748 & 2.702 & 2.016 & 3.619 \\
\hline JB test (p-values) & 0 & 0 & 0 & 0 & 0 \\
\hline \multicolumn{6}{|c|}{ Platinum } \\
\hline Mean & 0 & 0 & 0 & 0 & 0 \\
\hline Standard deviation & 1.051 & 0.740 & 0.521 & 0.361 & 0.247 \\
\hline Skewness & -0.337 & -0.137 & -0.002 & -0.112 & -0.009 \\
\hline Kurtosis & 13.408 & 7.077 & 4.426 & 2.479 & 0.644 \\
\hline JB test (p-values) & 0 & 0 & 0 & 0 & $8.66 \mathrm{E}-15$ \\
\hline
\end{tabular}




\begin{tabular}{|c|c|c|c|c|c|}
\hline $\begin{array}{c}\text { Descriptive statistics } \\
\text { of selected assets }\end{array}$ & D1 & D2 & D3 & D4 & D5 \\
\hline \multicolumn{6}{|c|}{ Palladium } \\
\hline Mean & 0 & 0 & 0 & 0 & 0 \\
\hline Standard deviation & 1.532 & 1.133 & 0.734 & 0.517 & 0.372 \\
\hline Skewness & 0.035 & -0.010 & -0.115 & -0.058 & -0.157 \\
\hline Kurtosis & 8.689 & 3.691 & 2.088 & 1.655 & 1.244 \\
\hline JB test (p-values) & 0 & 0 & 0 & 0 & 0 \\
\hline
\end{tabular}

Notes: JB stands for p-value of Jarque-Bera coefficients of normality.

Source: Authors' calculation

Table 1 discloses concise multiscale wavelet statistics including the mean, standard deviation, skewness, kurtosis and Jarque-Bera normality test. Means of all series and at all wavelets converge to zero, while all wavelet standard deviations decrease at higher scales, which is expected since higher wavelet scales are smoother. The skewness is found to be low with both positive and negative signs across assets and wavelets, while the level of kurtosis decreases at higher scales. Low JB p-values at all wavelet scales indicate that all presented wavelet series display nonnormal properties. Since we decompose the daily asset series with MODWT with Daubechies wavelet filter (DWT), it guarantees that the resulting DWT coefficients are stationary as contended by Gencay et al. (2002), thus unit root tests are not presented in Table 1. Due to space brevity, in the following we show graphical images of five MODWT wavelets only for RTS index, while wavelet plots of other assets can be acquired by request. 
Dejan Živkov, Jovan Njegić, Mirela Momčilović • Bidirectional spillover effect between...

Figure 1: MODWT decomposition of RTS index for five scales
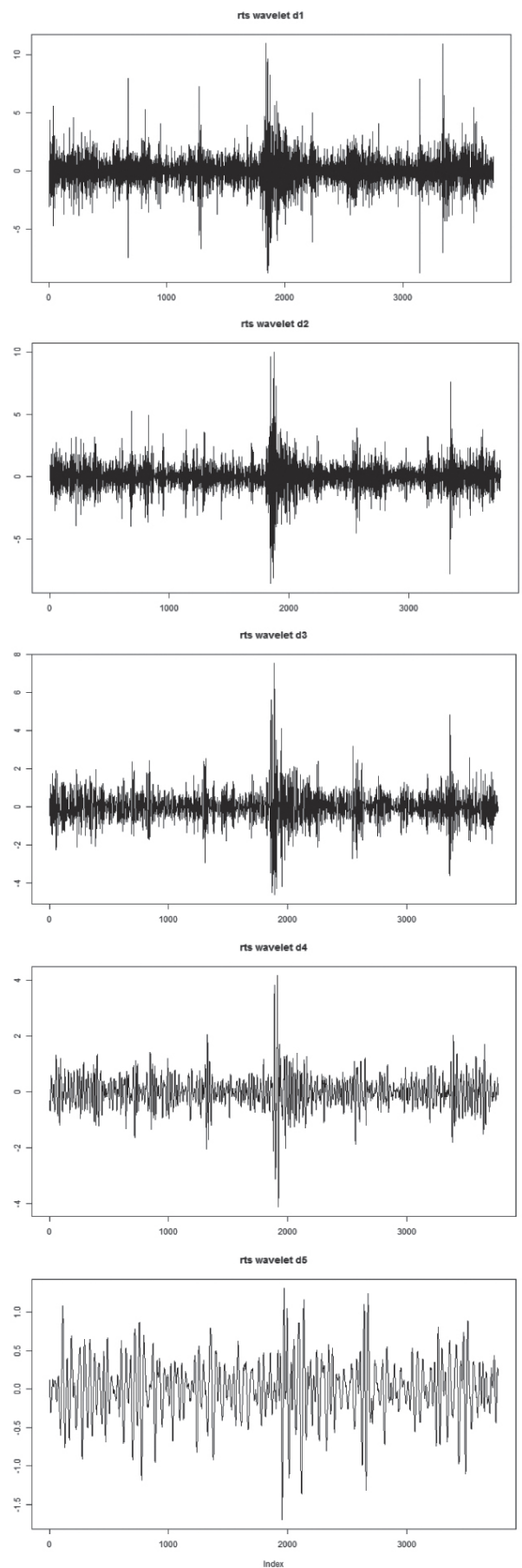

Source: Authors' calculation 
Figure 2 presents graphical image of detected structural breaks for empirical RTS log-returns that is calculated by modified ICSS algorithm. Detected structural breaks dates around the WFC are July 24, 2008 and August 3, 2009 and they are utilized to split whole sample into three subsamples - before, during and after the WFC and consequently gauge the spillover effect in these distinctive sub-periods.

Figure 2: Detected structural breaks with modified ICSS algorithm for empirical RTS $\log$ returns

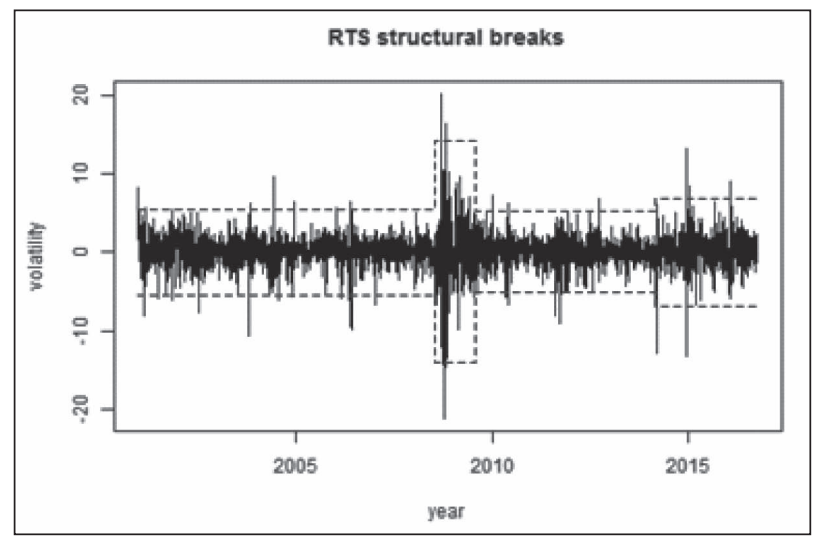

Note: Interrupted blue line denotes bands of \pm 3 standard deviations, whereby the change points are estimated by using the modified ICSS algorithm.

Source: Authors' calculation

\subsection{Bidirectional spillover effects}

This section reveals the results of bidirectional shock and volatility spillover effects between RTS index and selected commodities calculated via five wavelet scales, emphasizing the findings from the three distinctive time periods - before, during and after WFC. In such way, we can see whether and how spillover effect evolve over different wavelet scales and also how this effect varies between tranquil periods (before and after WFC) and the period of extreme market volatility (during the world financial crisis). By using wavelet decomposed series, we can gain an insight whether shock spillover effect last in extended period of time and how its strength differs at longer time-horizons. Due to space brevity, we present in Tables 2 and 3 only the off-diagonal parameter estimates of matrices A and B in BEKK-GARCH parameterization that measure bidirectional spillover effect across observed markets. Besides, it should be mentioned that some parameters in Tables 2 and 3 have negative sign, but since the parameters in BEKK model are shown in quadratic form the signs of the coefficients are irrelevant and they should be observed as absolute values. Table 2 reports the off-diagonal parameter results of 
six RTS-commodity pairs based on the five wavelet multi-resolution components, which corresponds to short-term (D1 and D2 scales) and mid-term (D3, D4 and D5 scales) fluctuations. Table 2 presents the results of full sample and the first subsample, while Table 3 contains the results of the remaining two subsamples.

Looking at the full sample results and via the five wavelet scales, unidirectional volatility spillover effect happens mostly from commodity markets toward Russian stock market, while shock spillover effect is significant (economically) only in case of gold at D2 scale $\left(a_{21(D 2)}=0.374\right)$ and platinum at D4 scale $\left(a_{21(D 4)}=1.021\right)$. It particularly applies for RTS-gold case in which RTS suffers volatility spillover impacts from gold up to forth wavelet, while gold not endures any shocks from Russian stock market whatsoever. The probable reason could lie in the fact that Russia is one of the biggest gold producer and gold-reserve holder in the world.

Brent, also, has one of the highest full-sample volatility spillover effects on RTS index $\left(b_{21(D 3)}=0.675\right)$. This coincide with the findings of Bhar and Nikolova (2009) who asserted that Russian equity returns and its conditional volatility are largely determined by oil price return spillovers. In addition, results reveal that platinum also has high effect at D3 and D4 scales $\left(b_{21(D 3)}=0.967, b_{21(D 4)}=1,284\right)$ as well as palladium at D3 scale $\left(b_{21(\mathrm{D} 3)}=0.687\right)$. On the other hand, commodities that are most affected by the increased volatility from the Russian market at full-sample are Brent oil at first and second scales $\left(b_{12(D))}=0.415, b_{12(D 2)}=0.490\right)$, gasoline at first, second and third scale $\left(b_{12(D))}=0.422, b_{12(D 2)}=0.441, b_{12(D)}=0.284\right)$, platinum at scale D2 $\left(b_{12(\mathrm{D} 2)}=0.200\right)$ and palladium at scale D2 and D3 $\left(b_{12(\mathrm{D} 2)}=0.162\right.$, $\left.b_{12(D 3)}=0.500\right)$. However, the results from the full sample should be observed and interpreted with caution because full-sample had various phases of erratic periods such as WFC. Thus, the average values of $a$ and $b$ parameters are probably erroneous and biased at full sample, which can confound market participant if they are used for granted. 
Dejan Živkov, Jovan Njegić, Mirela Momčilović • Bidirectional spillover effect between... Zb. rad. Ekon. fak. Rij. • $2018 \cdot$ vol. $36 \cdot$ no. $1 \cdot 29-53$

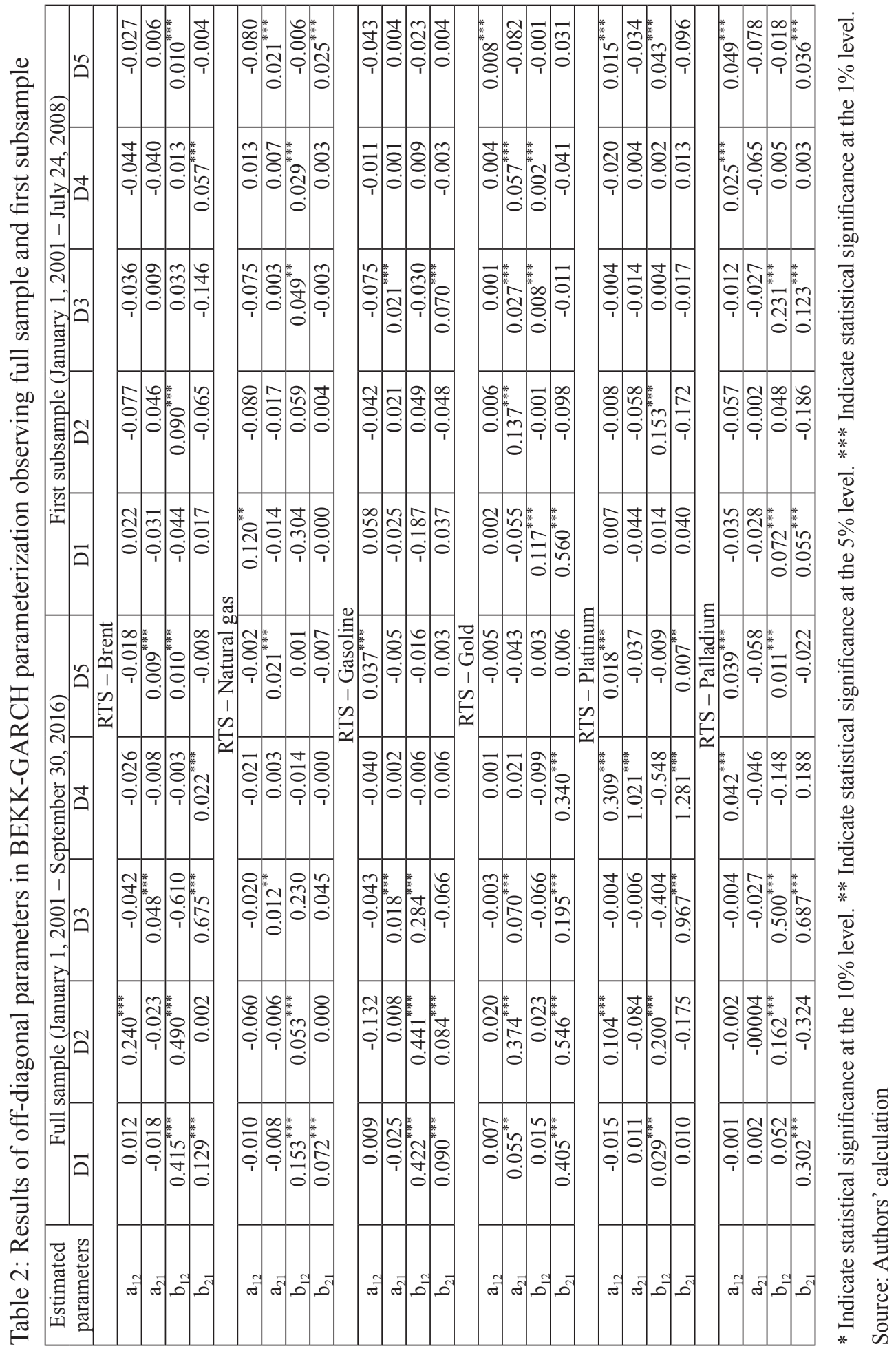


Dejan Živkov, Jovan Njegić, Mirela Momčilović • Bidirectional spillover effect between...

Zb. rad. Ekon. fak. Rij. • $2018 \cdot$ vol. $36 \cdot$ no. $1 \cdot 29-53$

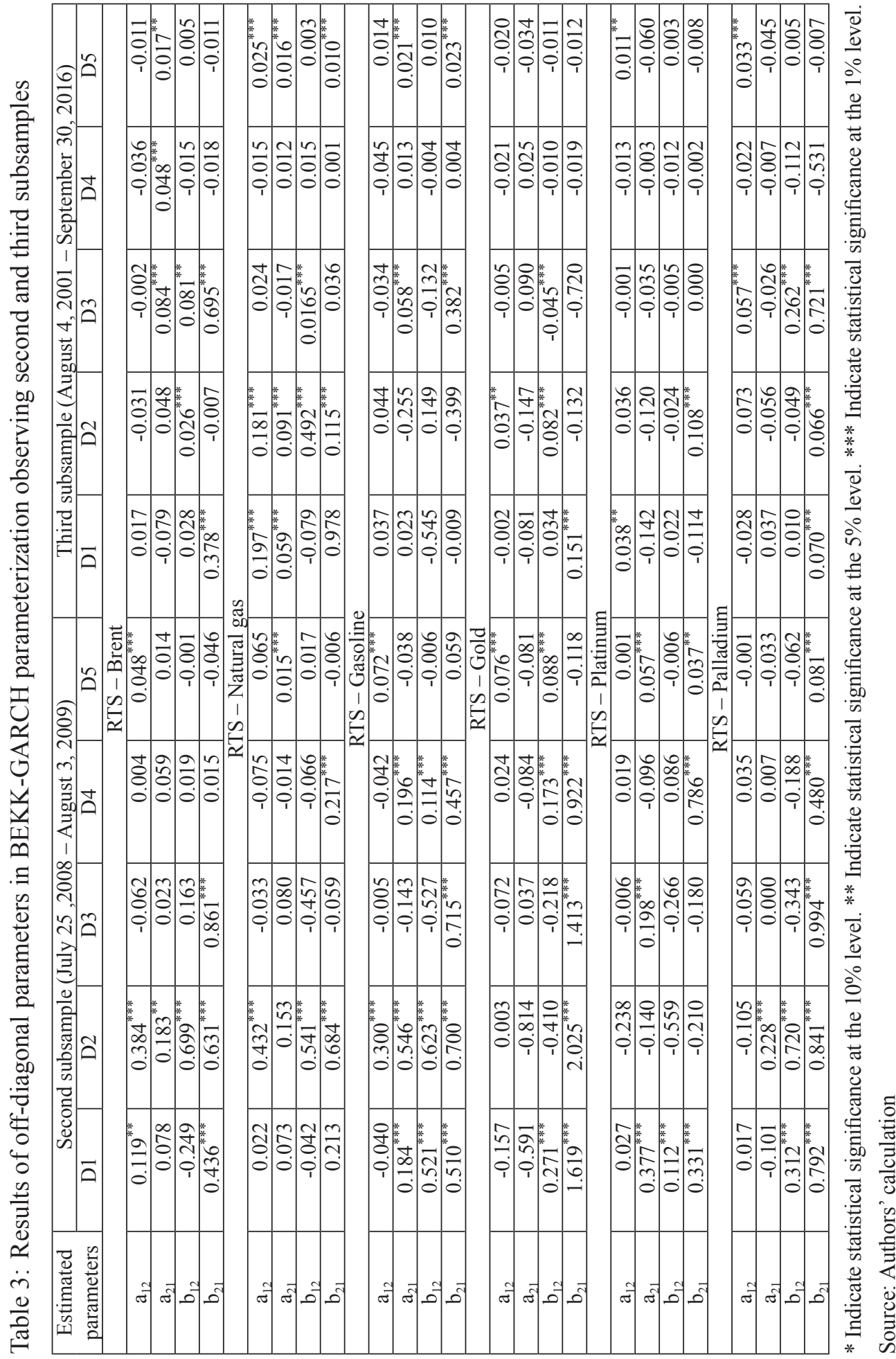


Therefore, beside full sample calculation, we consider spillover effects in three intrinsically different periods - before, during and after WFC. Tables 2 and 3 reveal the results of three subsamples It is obvious that results are fundamentally different between full sample and three shorter subsamples, which justifies our approach of full-sample division. According to Table 2, the spillover effects between RTS and selected commodities are generally very modest in the first subsample, which was relatively calm period. We find higher unidirectional shock spillover effect only in case from gold toward RTS at second wavelet scale $\left(a_{21(D 2)}=0.137\right)$, while for other commodities they are either very small or statistically insignificant. As for the volatility spillover effects, relatively stronger spillover effect is detected from gold toward RTS $\left(b_{2 l(D l)}=0.560\right)$ at scale D1, from palladium at scales D1 and D3 $\left(b_{21(D)}=0.055, b_{21(D)}=0.123\right)$ and from Brent at D4 $\left(b_{21(D 4)}=0.057\right)$. Economically significant reverse spillover effect is recorded only in cases from Russian stock market toward Brent at scale D2 $\left(b_{12(\mathrm{D} 2)}=0.090\right)$, gold at D1 $\left(b_{12(\mathrm{D} I)}=0.117\right)$, platinum at scale D2 $\left(b_{12(D 2)}=0.153\right)$ and palladium at scales D1 and D3 $\left(b_{12(D I)}=\right.$ $\left.0.072, b_{12(D 3)}=0.231\right)$.

At second subsample (during WFC), we record that off-diagonal spillover parameters $a$ and $b$ are statistically and economically significant more often, and at more time-horizons. In other words, spillover effect duration is extended and has higher intensity in comparison to first and third subsample. Also, in some instances, both shock and volatility spillover effects are bidirectional, as in the cases of RTSBrent oil $\left(a_{12(D 2)}=0.384, a_{21(D 2)}=0.183, b_{12(D 2)}=0.699, b_{21(D 2)}=0.631\right)$ and RTSgasoline $\left(a_{12(\mathrm{D} 2)}=0.300, a_{21(\mathrm{D} 2)}=0.546, b_{12(\mathrm{D} 2)}=0.623, b_{21(\mathrm{D} 2)}=0.700\right)$ at scale D2. These results are in line with research of Liu et al. (2017), who investigated the linkage between WTI oil and Russian index MICEX via four wavelet scales and found significant bidirectional and unidirectional transmissions between the two markets across all wavelet scales during the world crisis. On the other hand, for some RTS-commodity pairs only volatility spillover effect is bidirectional as in the cases of RTS-gold at D1 and D4 scales $\left(b_{12(D I)}=0.271, b_{21(D I)}=1.619, b_{12(D I)}=\right.$ $\left.0.123, b_{21(D l)}=0.922\right)$, RTS-platinum at D1 scale $\left(b_{12(D l)}=0.112, b_{21(D l)}=0.331\right)$ and RTS-palladium at D1 and D2 scales $\left(b_{12(D I)}=0.312, b_{21(D I)}=0.792, b_{12(D I)}=0.720\right.$, $\left.b_{21(D l)}=0.841\right)$. Except for RTS-Brent pair, for all other cases in which bidirectional spillover effect is detected, shocks from commodity markets had higher impact on RTS index than other way around. It can be noticed that all commodities have very high volatility spillover effects at various time-horizons, whereby gold has an exceptionally intense influence on RTS index at first four scales. This could be explained by the fact that Russia is at top three gold producers in the world and at the same time possesses huge amounts of gold reserves, whereby if value of gold decreases it could affect exchange rate stability with the serious repercussions for entire economy. Also, the protracted period of volatility spillover effects is recorded from palladium, gasoline and Brent commodity markets, whereby these markets affected Russian stock market at first four, four and three wavelet-scales, 
respectively. These findings of very powerful spillover effect between Russian index and some commodities during WFC could be an indication of commodity financialization. As Karyotis and Alijani (2016) and Olson et al. (2014) explained, this phenomenon could influence the spillover volatility effect and raise the level of correlation between markets. The commodity financialization is the process of vast capital inflows in commodity markets that led to integration of these markets with other financial markets, whereas huge inflows can cause up-trending of the marketplace (see Adams and Glück, 2015). Conversely, negative financializaton occurs in the crisis periods when immense capital funds abruptly and swiftly leave commodity and stock markets, in the herding behavior style, causing steep price fall. Thus, it is probable that capital outflows influenced spillover effects during WFC.

As for the third subsample, this period is relatively calm and spillover transmissions between markets are not as conspicuous as in the crisis period. It means that shock and volatility spillover effect are less frequent, they happen in smaller magnitudes and their duration is shorter, which is similar to the first subsample. We find that increased shock and volatility from Brent oil market transmitted to RTS index in third scale, that is, with some delay $\left(a_{12(D 3)}=0.084, b_{21(D 3)}=0.695\right)$ and such result is also reported in RTS-gasoline relation $\left(a_{12(D 3)}=0.058, b_{21(D 3)}=0.382\right)$. Palladium, beside Brent oil, has the highest volatility spillover effect $\left(b_{12(D)}=\right.$ 0.721) on Russian index, while other commodities have much smaller impact in third subsample. Regarding the reverse effect, shocks from Russian stock market influenced natural gas at short run, namely, at D1 and D2 scales $\left(a_{12(\mathrm{D} l)}=0.197\right.$, $\left.a_{21(D 2)}=0.181\right)$, whereas palladium is also affected but at much smaller extent $\left(a_{12(D 3)}=0.057\right)$ at mid-term horizon. Volatility spillover transmission from Russian stock market is economically significant only for Brent oil at mid-term $\left(b_{12(D 3)}=\right.$ $0.081)$, for natural gas at short-term $\left(b_{12(D 2)}=0.492\right)$ and for palladium at mid-term $\left(b_{12(D 3)}=0.262\right)$.

Taking into account that assessed spillover effects in first and third subsamples significantly deviate in magnitude and frequency from the second subsample counterparts, it can be said that full sample off-diagonal $a$ and $b$ parameters are biased. Thus, full sample division and accompanying parameters' estimation for every subsample, provides much more accurate and more reliable point-estimates for interested market participants.

\subsection{Complementary analysis via wavelet coherence}

Beside previously analyzed spillover effect, this section tries to comprehend the level of scale dependent correlation between RTS index and selected commodities, since portfolio managers and policy makers have high interest to learn, as much as possible, about time-frequency correlation characteristics. The correlation strength 
between analysed series is scrutinized via wavelet coherence (WTC), which is displayed via a contour plot that ranges from blue (low coherence, near zero) to red (high coherence, near one). Figure 3 presents six wavelet square coherence spectrum plots between RTS index and the selected commodities.

As can be seen, the colour spectrum in all WTC plots is predominantly in blue and green at high frequencies throughout all sample, which is a sign of a low correlation between RTS index and selected commodities.

Figure 3: Wavelet coherence spectrum plots between RTS index and the selected commodities
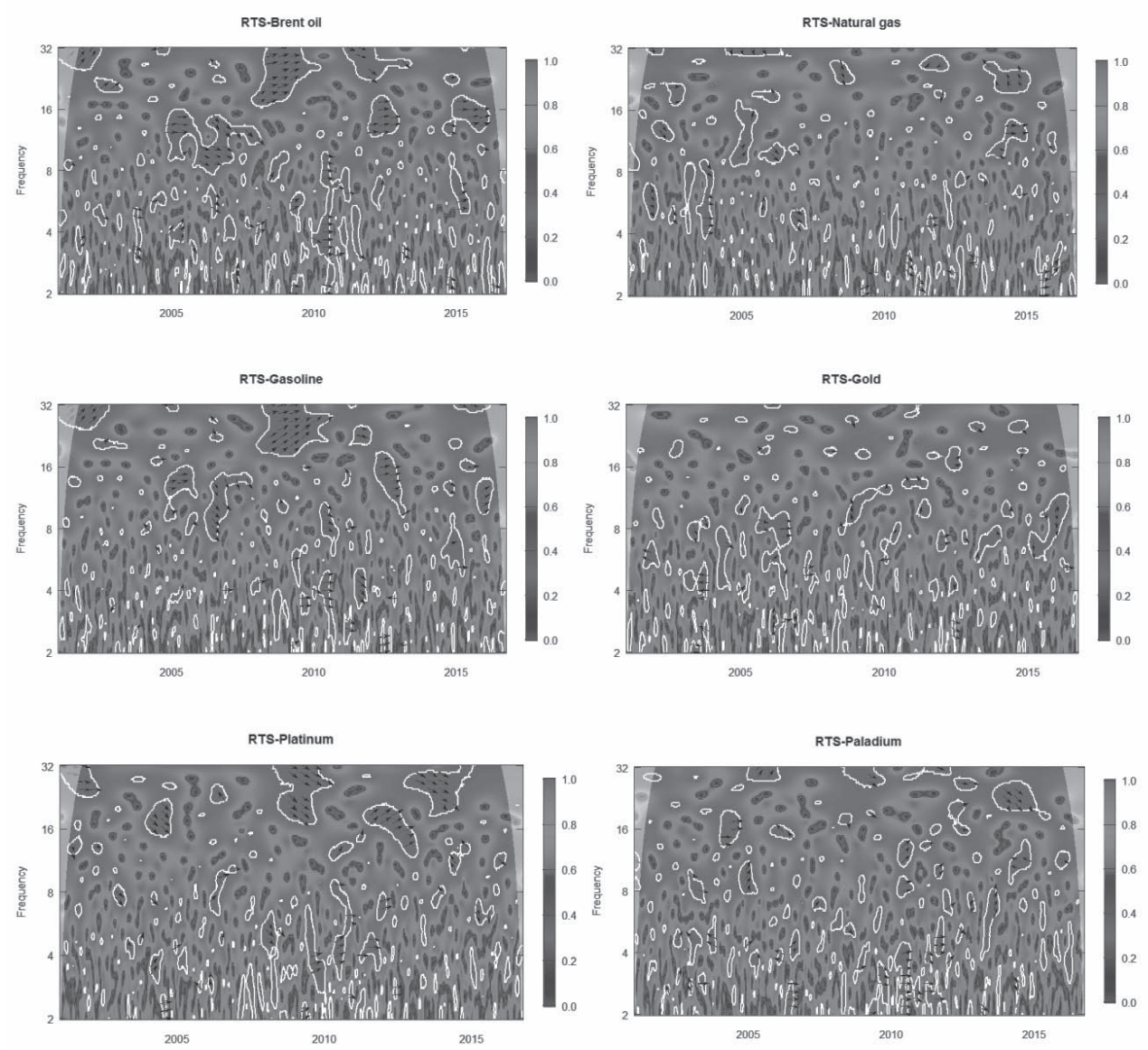

Note: Left vertical axis represents frequency component, which goes up to fifth scale (32 days). The strength of the co-movement is measured via color surfaces at right vertical axis, were blue and green colors signify low coherence, while wormer colors point to a higher coherence.

Source: Authors' calculations 
These results indicate that short-term investors can use selected commodities for diversification purposes in portfolio with RTS index. At low wavelet scales, we notice that in some WTC plots, such as RTS-Brent, -platinum and -palladium there are relatively small areas of dark red, which indicates the stronger co-movements between observed assets. These higher correlations are recorded around 2009, 2010 and 2011, which are the periods of enhanced market turmoil, that is, when the global economy was struck by WFC and subsequently by sovereign debt crisis in Europe and the U.S. The enhanced correlation between stock and commodity markets facilitates volatility spillovers between these markets, particularly in bubble burst periods when institutional investors rebalance their portfolios and move their funds to other, less risky asset classes. These findings are in line with strong spillover effects that were found in the second subsample in the previous section. Also, red patches are found in RTS-Brent plot around 2015, which was the year when oil prices plummeted. Referring to Karyotis and Alijani (2016) and Olson et al. (2014) these results very likely depict a negative commodity financialization, an occurrence when vast capital streams change marketplace in search of safe havens. As for midterm investors, our results suggest that most optimal portfolio combination would be RTS with either natural gas or gold. This conclusion is drawn due to the fact that natural gas and gold have the lowest number of dark red areas, even at the higher wavelet scales.

\section{Results and discussion}

Taking into account our spillover findings from the previous section, the most appropriate auxiliary assets in combination with RTS would be gold or natural gas in calm periods because shock and volatility transmission from gold and natural gas toward Russian stock market occurs rarely and at relatively low magnitudes, observing all wavelet scales. Nevertheless, in periods of extreme market turbulence, volatility spillover effect is very strong from gold toward RTS, which is not the case for natural gas. Thus, natural gas should be coupled with RTS in crisis periods. Besides, WTC reveals that these commodities have very low coherence with RTS index, during tranquil and crisis time, even at the highest wavelet scales, which makes them suitable for diversification purposes.

Following Tiwari et al. (2016), the squared wavelet coherence coefficients are presented in absolute value, thus the negative correlations (if exist) cannot be seen directly via coherence spectrum plots. In that manner, we perform wavelet phase difference method, which can be handy for distinguishing between positive and negative correlations. In addition, the position of phase difference arrows can indicate which observing asset has the leading role over another asset. According to Figure 3, the vast majority of arrows in red areas are pointed to the right, which means that time series are highly positively correlated in these particular periods 
and mostly at the higher wavelet scales. This is not surprizing, since Russia is a major producer of these commodities, and every change in the commodity prices reflects on the Russian stock index. This particularly applies for oil production, since five oil companies accounted for approximately $19 \%$ of the total stock market capitalization in 2008 (see Bhar and Nikolova, 2010).

This is consistent with our results, in which the wide dark red areas are most pronounced in cases of RTS-Brent and RTS-gasoline during 2009, which was the period of WFC. Such high coherence was probably caused by rapid fleeing of capital funds from Russian stock market as well as certain commodity markets (Brent and gasoline in particular) in WFC period. It speaks in favour of negative commodity financialization, a factor that probably has a major role in high spillover effect as well. Besides, it can be seen that up (down) inclination of arrows are not consistent, which means that lead/lag relationship frequently shifts, and this is most obvious in the case of RTS-platinum.

\section{Conclusion}

This paper endeavors to investigate the shock and volatility transmission effect between six futures commodities (Brent oil, natural gas, gasoline, gold, platinum and palladium) and Russian index - RTS. Thorough and in-depth analysis was done via five different frequency dimensions using MODWT series, which extended our research into joint time-frequency domain. Utilizing wavelet decomposed series, we can learn whether shock spillover effect last in prolonged period of time and how its strength differs at shorter (longer) time-horizons. Besides, since our observed period comprise relatively long time-span of almost 16 years, which is permeated with tranquil and crisis periods, we divided fullsample into three subsamples - before, during and after WFC. The division was done via non-arbitrary method of structural breaks detection - modified ICSS algorithm.

The results indicate that off-diagonal point estimates ( $a$ and $b$ ) significantly deviate between subsamples in terms of its magnitude and statistical significance, which speaks in favor of full-sample division. Generally, we find that spillover effects took place mostly from the commodity markets toward RTS index in full-sample as well as in three subsamples. During relatively calm periods (first and third sub-periods), spillover effects are very moderate and they occur in relatively few wavelet scales, which pointed that duration of this effect is limited in peaceful times. On the other hand, at second subsample (during WFC), we document that off-diagonal spillover parameters $a$ and $b$ are statistically and economically significant more often, spillover effect duration is extended and at higher intensity in comparison to the first and third subsample. Gold has an exceptionally intense influence on 
RTS index at first four scales, which exclude gold as appropriate asset in portfolio with RTS during extreme market occurrences. In addition, the protracted period of volatility spillover effects toward RTS is also recorded from palladium, gasoline and Brent. As a complementary analysis, we gauged scale-dependent correlation strength between analysed series via wavelet coherence. We find that for pairs such as RTS-Brent, -gasoline and -platinum there are areas, which point to the stronger co-movements between observed assets in period of WFC at higher wavelet scales, and these results could indicate to negative commodity financialization. On the other hand, wavelet coherence disclosed that gold and natural gas have very low coherence with RTS index, during both tranquil and crisis periods, even at the highest wavelet scales, which makes them suitable for diversification purposes. Therefore, taking into account both spillover effect and wavelet coherence, our findings favor natural gas as most convenient auxiliary asset in portfolio with RTS index.

This paper contributes to the international literature by shedding a new light on question how spillover effects transfer bidirectionally between some of the most important global commodities and the Russian stock index. At the same time, the paper gauges the size of these effects that ensue at different time horizons. The findings may enable various market participants, who have different term objectives, such as commodity producers, consumers and commodity (equity) investors, to take well-informed decisions based on the prevention of unwanted volatility shocks. In particular, investors who tend to diversify their investments can use the results of this study as crucial inputs to hedge spillover effects by resorting on variance swaps, equity futures or purchasing options.

\section{References}

Adams, Z., Glück, T. (2015) "Financialization in commodity markets: A passing trend or the new normal?", Journal of Banking and Finance, Vol. 60, pp. 93111, doi: 10.1016/j.jbankfin.2015.07.008.

Arouri, M.E.H., Rault, C. (2012) "Oil prices and stock markets in GCC countries: empirical evidence from panel analysis", International Journal of Finance and Economics, Vol. 17, No. 3, pp. 242-253, doi: 10.1002/ijfe.443.

Barunik, J., Vacha, L. (2013) "Contagion among Central and Eastern European Stock Markets during the Financial Crisis", Czech Journal of Economics and Finance-Finance a uver, Vol. 63, No. 5, pp. 443-453.

Bein, M.A., Aga, M. (2016) "On the linkage between the international crude oil price and stock markets: Evidence from the Nordic and other European oil importing and oil exporting countries", Romanian Journal of Economic Forecasting, Vol. 19, No. 4, pp. 115-134. 
Bhar, R., Nikolova, B. (2009) "Oil Prices and Equity Returns in the BRIC Countries", The World Economy, Vol. 32, No. 7, pp. 1036-1054, doi: 10.1111/j.14679701.2009.01194.x.

Bhar, R., Nikolova, B. (2010) "Global oil prices, oil industry and equity returns: Russian experience", Scottish Journal of Political Economy, Vol. 57, No. 2, pp. 169-186, doi: 10.1111/j.1467-9485.2010.00512.x.

Bjornland, H.C. (2009) "Oil price shocks and stock market booms in an oil exporting country", Scottish journal of political economy, Vol. 56, No. 2, pp. 232-254, doi: 10.1111/j.1467-9485.2009.00482.x.

Conlon, T., Cotter, J. (2012) "An empirical analysis of dynamic multiscale hedging using wavelet decomposition", Journal of Futures Markets, Vol. 32, No. 3, pp. 272-299, doi: 10.1002/fut.20519.

Cunado, J., de Gracia, F.P. (2014) "Oil price shocks and stock market returns: evidence for some European countries", Energy Economics, Vol. 42, pp. 365377, doi: 10.1016/j.eneco.2013.10.017.

Dajčman, S. (2013) "Interdependence between some major European stock markets - A wavelet led/lag analysis", Prague Economic Papers, Vol. 22, No. 1, pp. 28-49, doi: 10.18267/j.pep.439.

Engle, R.F., Kroner, K.F. (1995) "Multivariate simultaneous generalized ARCH", Econometric Theory, Vol. 11, No. 1, pp. 122-150, doi: 10.1017/s0266466600009063.

Filis, G., Chatziantoniou, I. (2014) "Financial and monetary policy responses to oil price shocks: evidence from oil-importing and oil-exporting countries", Review of Quantitative Finance and Accounting, Vol. 42, No. 4, pp. 709-729, doi: 10.1007/s11156-013-0359-7.

Gencay, R., Selcuk, F., Whitcher, B. (2002) An Introduction to Wavelets and Other Filtering Methods in Finance and Economics, Academic Press, New York.

Hayo, B., Kutan, A.M. (2005) "The impact of news, oil prices, and global market developments on Russian financial markets", Economics of Transition, Vol. 13, No. 2, pp. 373-393, doi: 10.2139/ssrn.517664.

Hegerty, S.W. (2016). "Commodity-price volatility and macroeconomic spillovers: Evidence from nine emerging markets", North American Journal of Economics and Finance, Vol. 35, pp. 23-37, doi: 10.1016/j.najef.2015.10.014.

Ho, L-C., Huang, C-H. (2016) "Nonlinear relationship between oil price and stock index - Evidence from Brazil, Russia, India and China", Romanian Journal of Economic Forecasting, Vol. 19, No. 3, pp. 116-126.

Inclan, C., Tiao, G.C. (1994) "Use of cumulative sums of squares for retrospective detection of changes of variance", Journal of the American Statistical Association, Vol. 89, No. 427, pp. 913-923, doi: 10.2307/2290916.

Karyotis, C., Alijani, S. (2016) "Soft commodities and the global financial crisis: implications for the economy: resources and institutions", Research in 
International Business and Finance, Vol. 37, pp. 350-359, doi: 10.1016/j. ribaf.2016.01.007.

Kirkulak-Uludag, B., Lkhamazhapov, Z. (2017) "Volatility Dynamics of Precious Metals: Evidence from Russia", Czech Journal of Economics and Finance Finance a uver, Vol. 67, No. 4, pp. 300-317.

Kurshid, M., Uludag, B.K. (2017) "Shock and volatility spillovers between oil and some Balkan stock markets", Romanian Journal of Economic Forecasting, Vol. 20, No. 4, pp. 47-59.

Liu, X., An, H., Huang, S., Wen, S. (2017) "The evolution of spillover effects between oil and stock markets across multi-scales using a wavelet-based GARCH-BEKK model", Physica A: Statistical Mechanics and its Applications, Vol. 465, pp. 374-383, doi: 10.1016/j.physa.2016.08.043.

Mahmoodi, A. (2017) "Oil price reduction impacts on the Iranian economy", Zbornik radova Ekonomskog fakulteta u Rijeci: Časopis za ekonomsku teoriju i praksu, Vol. 35, No. 2, pp. 353-374, doi: 10.18045/zbefri.2017.2.353.

Mensi, W., Beljid, M., Boubaker, A., Managi, S. (2013) "Correlations and volatility spillovers across commodity and stock markets: Linking energies, food, and gold", Economic Modelling, Vol. 32, pp. 15-22, doi: 10.1016/j.econmod. 2013.01.023.

Mensi, W., Hammoudeh, S., Nguyen, D.K., Kang, S.H. (2016) "Global financial crisis and spillover effects among the U.S. and BRICS stock markets", International Review of Economics and Finance, Vol. 42, pp. 257-276, doi: 10.1016/j.iref.2015.11.005.

Nazlioglu, S., Erdem, C., Soytas, U. (2013) "Volatility spillover between oil and agricultural commodity markets", Energy Economics, Vol. 36, pp. 658-665, doi: 10.1016/j.eneco.2012.11.009.

Narayan, P.K., Narayan, S. (2010) "Modelling the impact of oil prices on Vietnam's stock prices", Applied Energy, Vol. 87, No. 1, pp. 356-361, doi: 10.1016/j. apenergy.2009.05.037.

Njegić, J., Živkov, D., Janković, I. (in press) "Interrelationship and spillover effect between stock and exchange rate markets in the major emerging economies", Prague Economic Papers, doi: 10.18267/j.pep.669.

Olson, E., Vivian, A.J., Wohar, M.E. (2014) "The relationship between energy and equity markets: evidence from volatility impulse response functions", Energy Economics, Vol. 43, pp. 297-305, doi: 10.1016/j.eneco.2014.01.009.

Raza, N., Shahzad, S.J.H., Tiwari, A.K., Shahbaz, M. (2016) "Asymmetric impact of gold, oil prices and their volatilities on stock prices of emerging markets", Resources Policy, Vol. 49, pp. 290-301, doi: 10.1016/j.resourpol.2016.06.011.

Sansó, A., Aragó, V., Carrion-i-Silvestre, J. (2004) "Testing for changes in the unconditional variance of financial time series", Revista de Economia Financiera, Vol. 4, No. 1, pp. 32-53. 
Singhal, S., Ghosh, S. (2016) "Returns and volatility linkages between international crude oil price, metal and other stock indices in India: Evidence from VARDCC-GARCH models", Resources Policy, 50, pp. 276-288, doi: 10.1016/j. resourpol.2016.10.001.

Shamsollah, S., Maryam, M.B. (2011) "An evaluation of asymmetric effects of oil export shocks on non-tradable sector of Iranian economy", Romanian Journal of Economic Forecasting, Vol. 14, No. 1, pp. 106-124.

Tiwari, A.K., Mutascu, M.I. and Albulescu, C.T. (2016). "Continuous wavelet transform and rolling correlation of European stock markets", International Review of Economics and Finance, Vol. 42, pp. 237-256, doi: 10.1016/j. iref.2015.12.002.

Torrence, C., Webster, P.J. (1999) "Interdecadal changes in the enso-monsoon system", Journal of Climate, 12(8), pp. 2679-2690, doi: 10.1175/15200442(1999)012<2679:icitem>2.0.co;2.

Vacha, L., Barunik, J. (2012) "Co-movement of energy commodities revisited: Evidence from wavelet coherence analysis", Energy Economics, Vol. 34, No. (1), pp. 241-247, doi: 10.1016/j.eneco.2011.10.007.

van der Ploeg, F., Poelhekke, S. (2009) "Volatility and the natural resource curse", Oxford Economic Papers, Vol. 61, No. (4), pp. 727-760, doi: 10.1093/oep/ gpp027.

Yildirim, N., Ozcelebi, O., Ozkan, S. O. (2015) "Revisiting the impacts of oil price increases on monetary policy implementation in the largest oil importers", Zbornik radova Ekonomskog fakulteta u Rijeci: Časopis za ekonomsku teoriju i praksu, Vol. 33, No. 1, pp. 11-35.

Živkov, D., Balaban, S., Đurašković, J. (in press) "What Multiscale Approach Can Tell about the Nexus between Exchange Rate and Stocks in the Major Emerging Markets?", Czech Journal of Economics and Finance - Finance a uver. 


\title{
Dvosmjerni učinak prelijevanja između ruskog burzovnog indeksa i odabranih roba
}

\author{
Dejan Živkov ${ }^{1}$,Jovan Njegićn ${ }^{2}$, Mirela Momčilović3
}

\begin{abstract}
Sažetak
Ovaj rad istražuje učinak prelijevanja šoka i volatilnosti između ruskog indeksa RTS $i$ šest robnih terminskih ugovora (Brent nafta, prirodni plin, benzin, zlato, platina $i$ paladij), promatrajući zajedničku vremensko- frekvencijsku domenu preko wavelet razloženih serija. Zbog činjenice da je promatrano vremensko razdoblje od gotovo 16 godina prožeto mirnim i kriznim razdobljima, podijelili smo puni uzorak u tri pod-uzorka: prije, za vrijeme i nakon Svjetske financijske krize putem modificiranog ICSS algoritma. Smatramo da se učinci prelijevanja odigravaju uglavnom od tržišta roba prema RTS indeksu u sva tri pod-uzorka. Međutim, tijekom relativno mirnih razdoblja (prva i treća podskupina) učinci prelijevanja su vrlo umjereni i javljaju se u relativno malim wavelet razinama, što ukazuje da je trajanje ovih učinaka ograničeno u mirnim periodima. S druge strane, trajanje učinaka prelijevanja i njezin intenzitet porasli su tijekom Svjetske financijske krize. Također, wavelet koherentnost ukazuje na to da postoje područja većeg međusobnog kretanja u razdoblju Svjetske financijske krize kod viših wavelet razina za parove kao što su RTS-Brent, RTS-benzin i RTS-paladium. Robe koje imaju najjači učinak prijenosa na RTS indeks su Brent nafta, benzin i paladij, dok zlato ima snažnu prijenosnu volatilnost samo tijekom Svjetske financijske krize.
\end{abstract}

Ključne riječi: roba, učinak prelijevanja, MODWT, BEKK-GARCH, wavelet koherentnost

JEL klasifikacija: C51, C63, G15

1 Predavač, Visoka poslovna škola strukovnih studija iz Novog Sada, Vladimira Perića Valtera 4, Univerzitet u Novom Sadu, 21000 Novi Sad, Srbija. Znanstveni interes: ekonometrija, međunarodne financije, makroekonomija. Tel.: +38160 1445598. Fax: +381216350367. E-mail: dejanzivkov@gmail.com. Osobna web stranica: https://www.vps.ns.ac.rs/ (osoba za kontakt).

2 Profesor, Visoka poslovna škola strukovnih studija iz Novog Sada, Vladimira Perića Valtera 4, Univerzitet u Novom Sadu, 21000 Novi Sad, Srbija. Znanstveni interes: ekonometrija, portfelj financiranja, makroekonomija. Tel.: +3816250 2345. Fax: +38121635 0367. E-mail: jovan. nj@gmail.com.Osobnaweb stranica: https://www.vps.ns.ac.rs/.

${ }^{3}$ Asistent, Visoka poslovna škola strukovnih studija iz Novog Sada, Vladimira Perića Valtera 4, Univerzitet u Novom Sadu, 21000 Novi Sad, Srbija. Znanstveni interes: portfelj financiranja, poslovne financije, financijska tržišta. Tel.: +38163280 130. Fax: +38121635 0367. E-mail: bizniscentar@gmail.com.Osobnaweb stranica: https://www.vps.ns.ac.rs/. 